\title{
Economic Growth as a Driver of Transformation of Russian State Economic and Social Policy
}

\author{
Tatiana Ignatova ${ }^{*}$, Natalia Azhogina ${ }^{1}$, Antonina Pavlyukova ${ }^{2,3}$, and Grzegorz Sroslak $4^{4}$ \\ ${ }^{1}$ Russian Presidential Academy of National Economy and Public Administration, Moscow, Russia \\ ${ }^{2}$ Moscow State University of Technology and Management by the name of K.G.Razumovskiy (First \\ Cossack University), Moscow, Russia \\ ${ }^{3}$ Russian Customs Academy, Moscow, Russia \\ ${ }^{4}$ Jagiellonian University, Institute of Entrepreneurship, Crakow, Poland
}

\begin{abstract}
The purpose of the article is to identify the problems of sustainable development of Russia in the context of modern globalization processes and, based on a study of the factors of institutionalization of sustainable development, to propose directions of state policy to ensure it. The institutional methodology allowed the authors to study the genesis and development of the concept of sustainable development, as well as to highlight the structural features of Russian model of sustainable development. The logic of the article is focused on the analysis of the theory of sustainable development evolution, that made it possible to identify anomalies of Russian model and to develop public policy tools.
\end{abstract}

\section{Introduction}

The beginning of 2020 s is marked by the resignation of the old Government and the formation of the new Government of the Russian Federation, provoked by the guidelines expressed in the Address of the President to the Federal Assembly on modern measures of social and economic policy. It should be noted that the role of the country 's socioeconomic policy is enormous and its sphere of influence is not exhausted by the rate of economic growth, but the financial costs, transformed into concrete measures, have a completely pronounced socio-economic effect, where the economic component has financial indicators and the social effect is designed for the long term, to develop the socalled social potential, which prepares the ground for future economic effects.

\section{Methodology}

Economic growth, according to all key scientific economic schools, is mainly influenced by the following parameters: household disposable income, (national income net of net taxes), which is distributed among consumption and savings funds. In this regard, it is necessary to evaluate the options for the formation of these values in the context of the transformation of institutional parameters that form these values in the national economy.

\footnotetext{
*Corresponding author: tignatova1965@gmail.com
} 
The first parameter - disposable income of households - depends on the ability to create it, that is, the ability of economic entities to earn and, accordingly, the amount of net taxes, that is, the amount of tax payments that do not go to redistribution, but are used by the state "irretrievably." The main income in the economic system traditionally includes the following types of income: labour, business and property. Income earned by different groups of the population forms the disposable income of households, and its structure and redistribution to the formation of consumption flows and savings.

It is known that theoretical approaches critically consider the possibilities and necessity of distribution and redistribution of income in the economy, there are diametrically opposed views in the form of a classical liberal and egalitarian concept, as well as a partially reconciling utilitarian approach (Petty W. "The Tract on Taxes and Fees," Mor T. "The Golden Book is as useful as it is funny, about the best structure of the state and about the new structure of utopia"). As a rule, any extreme approach, is rejected both by theoretical thinking and through verification by empirical means. Therefore, it is generally accepted that redistribution is the norm of modern economic systems, and its degree may differ, and this determines the possibilities for further development of the national economy.

Thus, societies that tend to maintain the efficiency of a market entity prefer to minimize redistribution processes, because if an individual or company showing high rates of development, expressed in income growth, is expected to be effective in future periods, unless they attempt to undermine their functioning by imposing additional costs unrelated to business and/or the need to pay taxes. This approach is very effective in the short term.

Let us imagine a subject who is focused only on income growth and assume that all income growth is reinvested in an already effective business, then we will assume that with each new production cycle the amount of income growth increases and the overall efficiency increases. Assuming such ideal conditions, it is obvious that society is differentiated in terms of income received, and therefore it is very simple to rank the degree of efficiency, as it is equal to the amount of income received. Then the laws of nature are in force, and effective in its development continues to exist for as long as possible. Unfortunately or fortunately, economic reality is far from being a simplified model.

First, the next production cycle may have less efficiency than the previous one, because the production process will be suppressed by the lack of demand, the emergence of a competitor offering a similar product with new properties, etc. That is, the same subject can give different amounts of income, and therefore have different performance estimates. Besides, in our assumption, the individual was initially focused on income generation, his resources were not diverted or sprayed, which means that all efforts were directed to one point. Such an individual can exist only theoretically, as any person or enterprise is influenced by many factors that can spray his efforts, from ill health to unpredictable weather conditions. Besides, if he is focused on only one type of activity, he must give up all benefits, even as simple as communication. In this case, the meaning of his existence is that he is deprived of the opportunity to enjoy, or rather, all his pleasures are income gains. Once the pace of his income build-up falls, he is no longer considered an effective subject, meaning that all his past merits are offset. Thus, its effectiveness in the short term has positive consequences for it, and in the long term it does not. A society composed only of competing groups seeks to distribute income only through economic expediency prone to reduction, as does the development of competition leading to the formation of a monopoly, destroying relatively weak actors. That is, if the individual is not focused on various goals and values, his life ends where the decline in his income begins.

The model of universal equality in conditions of total redistribution is rejected by the very logic of existence and development: the same conditions do not determine the same efficiency because the uniqueness given from birth determines the possibilities of our 
achievements. The redistribution of income must therefore ensure the maintenance of life, and development opportunities must be created by the individual and the State themselves.

\section{Discussion}

Considering the differentiation of people's income in Russia, where according to the official data of Rosstat $12.9 \%$ of the population of the Russian Federation (or 18.9 million people) in 2018 received income below the subsistence minimum [1], which was 10038 rubles, we can conclude that almost 19 million people live below line of poverty? It should be noted that often incomes below the subsistence minimum per family member in Russia are received by citizens who have jobs, that is, who receive labor income [2].

Taxation of individual persons in Russian Federation is universal, income taxes are calculated on a flat scale. And in the period up to 2024 there will be no changes in rates or the emergence of a legally fixed minimum income, which is not subject to tax. However, it is worth noting that the calculation of the consumer basket and the costs provided for in it does not include the costs of taxation. So, according to Federal Law No. 227 of 03.12.12 "About a consumer basket in general across the Russian Federation", the following ratios of cost of nonfoods and services with the cost of food are established (as a percentage): nonfoods - 50, services - 50. Thus, the consumer basket involves 3 types of expenses: food, non-food goods and services. The consumer basket is the basis for calculating the minimum of money nominally sufficient for human existence. Thus, the calculation does not include household tax spending, which actually further distorts their disposable income. Thus, 18.9 million people in 2018 received incomes below the subsistence level, but their consumption was not carried out even in the amount assumed by the consumer basket, as it was actually reduced through the mechanism of payment of taxes.

As mentioned above, most of the President 's Address to the Federal Assembly was devoted to supporting low-income populations and families with children. Families with children are households with minimal incomes, as the birth of a child generally reduces a woman 's income opportunities, increases the family's costs, and accordingly reduces the average per capita income. The logic of the proposed measures is simple: the loss of "female income" is compensated by a benefit if the income per family member becomes below the subsistence minimum. That is, there is an alternative: a family can afford to give birth to a child, and a woman can raise it, and housing conditions can be improved by the family at the expense of maternal capital.

Even in the works of J. S. Mill it was assumed that the development of culture, diverse needs, life comfort gradually becomes a restriction of population growth. Poverty and fear of poverty are also powerful factors that constrain population growth.

Population statistics do not confirm an increase in fertility due to increased family availability. Economically developed countries tend to have a lower fertility rate than developing countries. Population studies on the distribution of disposable household resources in the Russian Federation confirm the global trend: families with three or more children have the lowest average per capita income, which in 2017 in such families amounted to 13268.1 rubles compared to 23593.3 rubles in families with one child [3]. Thus, there is no clear link between increased well-being and increased fertility [4]. Therefore, a measure aimed at supporting families with children, expressed in the form of direct cash payments to low-income families, will not lead to the goal of increasing fertility. In addition, these funds cannot fully meet the needs of the child, and therefore, in one way or another, the family or woman, will decide on the birth of the child based on its own prospects for its maintenance and development.

In our view, these funds should be used to finance children 's health care, organize preschool stay and development of children of pre-school age, organize the afternoon of 
school-age children, increase the financing of budgetary places for higher education. It is also certainly necessary to strengthen the value of the family in society, and for this purpose appropriate work must be carried out with the younger generation. The household should be oriented towards income on its own, but not through childbirth, and the desire to increase the family 's income can be created by providing conditions for a woman wishing to go to work by interrupting parental leave ahead of schedule.

In our view, creating income opportunities is more effective than redistributing income to the poorest [4]. In this regard, it is necessary to increase the number and quality of jobs, to focus the calculation of the minimum wage on the real possibility of maintaining life, to control the amount of illegal income and expenses, as households receiving equalization benefits are not always those with the lowest incomes, but more often those with hidden incomes.

The measure proposed by the Chairman of the Government of the Russian Federation, M.V. Mishustin, to monitor revenues seems appropriate. "All households in Russia will be entered into the information system within two years, and each income will be monitored from the beginning to the end to provide targeted social assistance," thus, digital control of business taxes is supposed to be extended to individuals [5].

However, the proposal made by M. V. Mishustin against easing the tax on the income of individuals and the irrelevant transition to a progressive tax conflicts with measures of social support of the population with minimal incomes. In our view, setting the amount of income free of income tax on individuals will reduce the cost of tax administration, reduce the need for targeted assistance. The progressive tax scale is necessary, on the one hand, to compensate for the lost revenues of the budget due to the emergence of income that will be considered unaffordable and, on the other, with the growth of income, the percentage ratio of tax to income becomes less tangible and does not have a significant impact on consumption.

So, having analyzed the differentiation of income and the possibilities of its formation and equalization, it should be recognized that at the moment in Russia there are mechanisms of redistribution, but there are insufficient opportunities to increase the income of families with children, as well as mechanisms of obtaining free social benefits that stimulate childbirth.

Further, the household consumption and savings fund and its role in the social and economic development of the State should be analysed.

The concepts of the life cycle of the individual (Keynesian, F. Modigliani, M. Friedman) state that both components are necessary, but the size and laws of formation of both parts of disposable income are assessed differently. All economists agree that money today is valued higher than money tomorrow, on the one hand, but on the other hand, intertime levelling of consumption is necessary. Therefore, the need to consume is due to the desire to maintain life today, and to save - tomorrow.

The classic political economists argued that the size of the savings was due to the amount of the interest rate. In addition to these obvious things, which to some extent affect the formation of consumption shares and savings, the factors of influence should include the peculiarities of mentality and traditions, the character of the person, the formed value guidelines. Thus, the poverty of a particular person may be affected by even a small increase in the interest rate if all other conditions contribute to it, and the interest rate has no effect on the other person. In our view, such an individual will be a person whose income does not allow saving in principle. Therefore, the J.M. criterion. Keynes is the most objective for most of the population (excluding the well-off and high-income group).

For macroeconomic growth, savings are necessary as a source of investment flows, consumption is a key characteristic of demand that stimulates the production of goods and services. The decline in demand comes in the face of falling income and rising household 
taxation. The Russian economy is currently experiencing both trends. Therefore, in the current period it is possible to increase consumption only with the help of credit, which in the short term really increases demand. However, debt-burdened households will not be able to maintain the current level of consumption in the future, as well as to afford to make the necessary investments in health and education.

In addition, the endless increase in consumption leads to the opposite problem of the economy - lack of savings undermines the potential of investment processes, and ensuring a normal amount of investment rests on the problem of translating all savings into real investment.

\section{Results}

For the Russian economy, the current greater problem is the decline in demand, not the lack of savings. The amount of savings in household disposable income essentially depends on the same factors as consumption, i.e. economic culture, current income, level of tax burden, in addition, neoclassicists argued that the size of savings is influenced by the amount of interest rate. However, the current economic situation indicates that the population is seeking to increase savings even in the face of lower deposit rates. According to the reporting of the Central Bank of the Russian Federation, for 01.01.2020 gain of deposits of the population in 12 months preceding reporting date was $7.3 \%$. At the same time, the maximum interest rate (on deposits in Russian rubles) of ten credit institutions attracting the largest volume of deposits of individuals in the specified period decreased from 7.5290 to $5.9270 \%$ [6]. In the following period, there has been a similar trend - there is a further decline in deposit rates.

The explanation for this phenomenon is the decline in real wealth in the face of falling real incomes of the population and pessimistic expectations. The perceived value of money becomes lower, which in turn makes it necessary to build up savings that are planned to be spent on large purchases or to be kept "on a black day." The expectation of a "black day" is now dominated by low economic growth, ruble depreciation, falling oil prices on the world market and a decline in business activity due to coronavirus.

Expectations actually shape future development trends, as the pessimistic attitude of households, caused by external and internal causes, leads to lower consumption and a desire to increase savings. However, in the context of pessimistic attitudes in society, household savings cannot be sources of investment, as similar expectations for the producer lead to the need to reduce production.

As noted above, the main group of social support measures is aimed at stimulating childbirth and supporting families with children, that is, budgetary expenditures on the social bloc are increasing. At the same time, it seems not quite logical in this situation to increase the retirement age and the minimum amount of indexation of labour and social pensions. Pensioners are a group of individuals who also carry out consumption and saving, while usually oriented towards consumption of domestic products, which is important within the framework of expansion of demand. In addition, it is this group of persons that is more vulnerable to the possibility of increasing revenues in other ways (except budgetary transfers).

In our view, social support should not always be in the form of direct cash payments. Apart from all quantitative indicators of economic growth, there are still qualitative indicators, such as free time and the development of the individual 's environment. Comfortable living conditions for citizens are formed by the amount of public goods that the state can provide free of charge: that is, the environment is determined by purely public (safety and law and order, improvement and quality of roads, etc.) and conditional public goods (level of education of the population and quality of medical services under OMS). It 
is in this area that there are large reserves for development in our country. The amount of free time and its growth without a decline in the country 's GDP also indicates an improvement in the standard and quality of life. The individual uses his free time for recuperation and self-development. In our view, the possibility of development and selfdevelopment of the population is a key economic resource for further economic growth. Citizens of Russia should have a stable benchmark that improving the standard and quality of life can be ensured through opportunities to improve skills and productivity, Additional education and retraining that can be obtained, including: And by State funding, as the key characteristic of the labour force is not its quantity, And qualitative potential to produce competitive products in the national economy.

\section{References}

1. The number of people with monetary income is lower than the subsistence minimum and the deficit of monetary income/Official website of the Federal Service of State Statistics//[Electronic resource] Access regime: http://old.gks.ru/wps/wcm/connect/rosstat_main/rosstat/ru/statistics/population/poverty / \#, free. Language: Russian.

2. T. Ignatova, A. Pavlyukova, L. Boldyreva, S. Solonina Management of consolidation processes in Russia: social and economic aspects. CBU International Conference on Innovations in Science and Education. Prague, Czech Republic, 21-23 March, Vol. 6, pp. 393-398. (2018).

3. T. Ignatova, T. Cherkasova. Integration of technological factors and institutional conditions for transition to an innovative type of economic growth. Journal of Economic Regulation, 10 (2), pp. 72-82. (2019)

4. E.D. Platonova, Yu.I. Bogomolova, S.Yu. Krasovsky Economy of resourses: reproduction approach. Monography. Moscow: APKiPPRO, 2013179 p.

5. Mishustin promised to unite all households in a control system for income / News of Interfax//Interfax.com [An electronic resource] the access Mode: https://www.interfax.ru/business/691408, free. RussianR. Botsman, R. Rogers What's Mine is Yours: The Rise of Collaborative Consumption (2010). - URL: http://appli6.hec.fr/amo/Public/Files/Docs/241_fr.pdfF.

6. Overview of the banking sector of the Russian Federation. Statistics//Official website of the Central Bank of the Russian Federation [Electronic resource] Access: https://cbr.ru/analytics/bnksyst/https://cbr.ru/analytics/bnksyst/, free. Language: Russian. 